\title{
Intravenous Immunoglobulin (IVIG) Significantly Reduces Respiratory Morbidity in COVID-19 Pneumonia: A Prospective Randomized Trial
}

Short Title: IVIG therapy for COVID-19

George Sakoulas, $\mathrm{MD}^{1,2,3}$, Matthew Geriak, PharmD ${ }^{1}$, Ravina Kullar, PharmD ${ }^{4}$, Kristina

L. Greenwood, PhD, $\mathrm{PhD}^{5}$, MacKenzie Habib, $\mathrm{BS}^{5}$, Anuja Vyas, MD ${ }^{1,2}$, Mitra

Ghafourian, $\mathrm{MD}^{1}$, Venkata Naga Kiran Dintyala, $\mathrm{MD}^{1}$, Fadi Haddad, $\mathrm{MD}^{6}$

1. Sharp Memorial Hospital, 7910 Frost Street, San Diego, CA 92123

2. Sharp Rees-Stealy Medical Group, 300 Fir Street, San Diego, CA 92101

3. Collaborative to Halt Antibiotic-Resistant Microbes (CHARM), Department of Pediatrics, University of California San Diego School of Medicine, 9500 Gilman Drive, La Jolla, CA 92093

4. Expert Stewardship, Inc, 201 Ocean Avenue, Santa Monica, CA 90402

5. Sharp Center for Research, 8695 Spectrum Center Blvd, San Diego, CA 92123

6. Sharp Grossmont Hospital, 5555 Grossmont Center Dr, La Mesa, CA 91942 


\section{${ }^{*}$ Corresponding author:}

George Sakoulas, MD, UCSD School of Medicine Biomedical Research Facility II, Room 4114, 9500 Gilman Drive, Mail Code 0760, La Jolla, CA 92093-0760; Phone: (858) 534-2325; FAX: (858) 246-1868; Email: gsakoulas@health.ucsd.edu

Keywords: COVID-19, SARS-CoV-2, IVIG

Conflicts of Interest: None

Funding: IVIG (Octagam 10\%) was provided by Octapharma USA, Hoboken, NJ 
medRxiv preprint doi: https://doi.org/10.1101/2020.07.20.20157891; this version posted July 25, 2020. The copyright holder for this preprint

(which was not certified by peer review) is the author/funder, who has granted medRxiv a license to display the preprint in perpetuity.

It is made available under a CC-BY-NC-ND 4.0 International license .

\section{Abstract}

Background. Interventions mitigating progression to mechanical ventilation in COVID-19 would markedly improve outcome and reduce healthcare utilization. We hypothesized that immunomodulation with IVIG would improve oxygenation and reduce length of hospital stay and progression to mechanical ventilation in COVID-19 pneumonia.

Methods. Patients with COVID-19 were randomized 1:1 to prospectively receive standard of care (SOC) plus IVIG $0.5 \mathrm{~g} / \mathrm{kg} /$ day $\times 3$ days with methylprednisolone $40 \mathrm{mg}$ 30 minutes before infusion versus SOC alone.

Results. 16 subjects received IVIG plus SOC and 17 SOC alone. The median age was 51 years for SOC and 58 years for IVIG. APACHE II scores and Charlson comorbidity indices were similar for IVIG and SOC (median 7.5 vs 7 and 2 for both, respectively). Seven SOC versus 2 IVIG subjects required mechanical ventilation $(p=0.12$, Fisher exact test). Among subjects with A-a gradient of $>200 \mathrm{~mm} \mathrm{Hg}$ at enrollment, the IVIG group showed i) a lower rate of progression to requiring mechanical ventilation (2/14 vs 7/12, $p=0.038$ Fisher exact test), ii) shorter median hospital length of stay (11 vs 19 days, $p=0.01$ Mann Whitney U), iii) shorter median ICU stay (2.5 vs 12.5 days, $p=0.006$ Mann Whitey $\mathrm{U}$ ), and iv) greater improvement in $\mathrm{PaO}_{2} / \mathrm{FiO}_{2}$ at 7 days (median [range] change from time of enrollment $+131[+35$ to +330$]$ vs $+44 \cdot 5[-115$ to +157$], p=0.01$, Mann Whitney-U test) than SOC.

Conclusion. This pilot prospective randomized study comprising largely of Latino patients showed that IVIG significantly improved hypoxia and reduced hospital length of stay and progression to mechanical ventilation in COVID-19 patients with A-a gradient $>200 \mathrm{~mm} \mathrm{Hg}$. 
medRxiv preprint doi: https://doi.org/10.1101/2020.07.20.20157891; this version posted July 25, 2020. The copyright holder for this preprint (which was not certified by peer review) is the author/funder, who has granted medRxiv a license to display the preprint in perpetuity. It is made available under a CC-BY-NC-ND 4.0 International license .

\section{Introduction}

COVID-19 infection, as is common with many types of viral and atypical infections, is characterized by a biphasic illness of a relatively mild protean phase driven by viral replication resolving in about a week, and second phase, driven by the immune response. The second phase may lead to potentially catastrophic disease manifestations requiring hospitalization and high-level medical care characterized by acute respiratory distress syndrome (ARDS), vasculitis with thrombotic complications, and multi-organ involvement. ${ }^{1-4}$ It is not surprising, therefore, that the clinical effects of remdesivir, and hydroxychloroquine, molecules with defined anti-viral activities in vitro and in vivo, are modest at best in treating COVID-19 hospitalized patients. ${ }^{5-8}$ Therefore, from a pathophysiological standpoint, clinically meaningful therapies for COVID-19 will likely emerge from immunomodulation. Several studies are under way investigating immunosuppressive agents, but many of these agents focus on potent inhibition of a single immunological target, including the interleukin-6 receptor inhibitor, tocilizumab. 9,- $^{-}$

${ }^{14}$ Unfortunately, many complex biological systems including the human immune response to infection, are highly redundant and therefore, attenuation of a single target may be bypassed, compromising clinical effectiveness of an agent which may be promising in laboratory settings. ${ }^{15}$ Furthermore, potent inhibition of specific pathways may come at a price of targeted immunosuppression and an increased risk of opportunistic infection, as seen in patients treated with these agents for autoimmune disease. $^{16}$

IVIG has been found to have broad therapeutic applications for the treatment of a variety of inflammatory, infectious, autoimmune, and viral diseases including Kawasaki 
disease. IVIG may modulate the immune response via multiple mechanisms including blocking a wide array of pro-inflammatory cytokines that potentially lead to severe inflammatory responses as well as Fc-gamma receptor binding of activated macrophages. ${ }^{18}$ There are published reports retrospectively showing potential benefit of IVIG treatment for COVID-19 ARDS in adults and the associated Kawasaki-like illness in children. ${ }^{19-24}$ This is the first study to prospectively evaluate the addition of IVIG to otherwise standard treatment for adults with moderate to severe hypoxemia secondary to COVID-19. 
medRxiv preprint doi: https://doi.org/10.1101/2020.07.20.20157891; this version posted July 25, 2020. The copyright holder for this preprint

(which was not certified by peer review) is the author/funder, who has granted medRxiv a license to display the preprint in perpetuity.

It is made available under a CC-BY-NC-ND 4.0 International license .

\section{Methods}

Study design. This was an open-label randomized controlled trial performed at two hospital centers: Sharp Memorial Hospital (San Diego, CA) and Sharp Grossmont Hospital (La Mesa, CA). The research protocol was approved by the Internal Review Board of the participating hospitals prior to patient enrollment and was registered on clinicaltrials.gov (April 28, 2020; NCT04411667). All participants provided informed consent electronically.

Study population. Adult patients $\geq 18$ years of age presenting with COVID-19 infection confirmed by positive polymerase chain reaction testing for SARS-CoV2 genome in nasopharyngeal or oropharyngeal swab sample were considered for inclusion if they demonstrated moderate to severe hypoxia $\left(\mathrm{sPO}_{2} \leq 96 \%\right.$ on $\geq 4$ liters $\mathrm{O}_{2}$ by nasal cannula) but not on mechanical ventilation. This corresponds to $\mathrm{FiO}_{2}$ of $37 \%$ to maintain a $\mathrm{PaO} 2$ of $90 \mathrm{~mm} \mathrm{Hg}$ (alveolar-arterial [A-a] gradient of $120 \mathrm{~mm} \mathrm{Hg}$ or $\mathrm{PaO}_{2} / \mathrm{FiO}_{2} 243$ ).

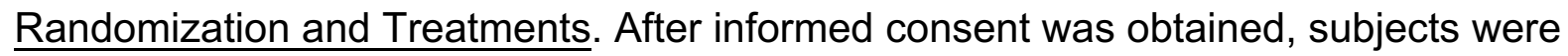
randomized 1:1 into treatment arm or standard of care (SOC) control arm. SOC consisted of the subject remaining on or being eligible for any treatment not part of a randomized clinical trial at the time of enrollment. On May 13, 2020 and afterwards, this included the use of remdesivir. Subjects were also allowed to receive convalescent plasma therapy as part of the nationally available compassionate use registry. The IVIG treatment arm consisted of the subject receiving IVIG (Octagam 10\% provided by Octapharma USA, Inc) $0.5 \mathrm{~g} / \mathrm{kg}$ daily for 3 days beginning on the day of enrollment in 
medRxiv preprint doi: https://doi.org/10.1101/2020.07.20.20157891; this version posted July 25, 2020. The copyright holder for this preprint (which was not certified by peer review) is the author/funder, who has granted medRxiv a license to display the preprint in perpetuity. It is made available under a CC-BY-NC-ND 4.0 International license .

addition to SOC. For subjects not already receiving glucocorticoid therapy, enrolled treatment arm subjects received methylprednisolone $40 \mathrm{mg}$ IV once 30 minutes before IVIG to mitigate headache commonly experienced after IVIG therapy. Enrollment in other clinical trials and the use of off-label agents (eg. tocilizumab) was not allowed while the subject was enrolled and monitored for progression to the endpoint of i) respiratory failure requiring receipt of mechanical ventilation (a composite of either receiving ventilation or the subject status changed to a do not resuscitate/do not intubate resulting in progressive respiratory failure and death) or ii) death from nonrespiratory causes prior to receipt of mechanical ventilation. If the subject progressed to mechanical ventilation, receipt of off-label agents and/or enrollment in other clinical trials was allowed. Subject hospital course was followed until hospital discharge or for 30days in the hospital after enrollment, whichever came first, for the purpose of total and intensive care unit (ICU) days of hospital days.

Clinical data extraction and analysis. Relevant clinical and laboratory information was captured to allow for group comparisons, including the calculation of Charlson comorbidity index (https://www.mdcalc.com/charlson-comorbidity-index-cci) and APACHE II acute illness severity score (https://www.mdcalc.com/apache-ii-score\#nextsteps). The alveolar-arterial (A-a) gradient was calculated (https://www.mdcalc.com/a-ao2-gradient) for each subject at the time of enrollment based on arterial blood gases when available or based on $\mathrm{PaO}_{2}$ extrapolated $\mathrm{SpO}_{2}$ and fraction of inspired oxygen $\left(\mathrm{FiO}_{2}\right)$. Interleukin-6 was measured from blood 24-48 hours after enrollment (https://ltd.aruplab.com/Tests/Pub/0051537). 
Statistical analysis. The initial goal of the pilot study was to enroll 20 patients (10 per arm). After 20 patients had reached the composite endpoint or discharged from the hospital, the data was reviewed by a data safety monitoring board (DSMB) consisting of 2 hospitalist physicians, 1 critical care physician, and 1 pharmacist/statistician. The DSMB voted to continue the study until the Phase 3 randomized placebo-controlled multi-center study of IVIG in COVID-19 (Octagam 10\% therapy in COVID-19 patients with severe disease; clinicaltrials.gov, NCT04400058, May 22, 2020) became available. All analyses were performed on the intent to treat population. Statistical differences in rates of receipt of mechanical ventilation and other categorical or ordinal variables were calculated using Fisher exact test, and differences in continuous variables were calculated using Mann Whitney-U. 
medRxiv preprint doi: https://doi.org/10.1101/2020.07.20.20157891; this version posted July 25, 2020. The copyright holder for this preprint

(which was not certified by peer review) is the author/funder, who has granted medRxiv a license to display the preprint in perpetuity.

It is made available under a CC-BY-NC-ND 4.0 International license .

\section{Results}

Baseline patient demographics and clinical characteristics. Between May 1 and June

16, 2020, 34 patients were randomized into the study as shown in Figure 1 (17 SOC, 17 IVIG). Immediately after randomization and notification of the principal investigator, one subject was immediately deemed unevaluable by the principal investigator and excluded due to a high risk of bacterial superinfection (elevated absolute neutrophil count of $9900 / \mathrm{mm}^{3}$ and concomitant procalcitonin of $1.45 \mathrm{ng} / \mathrm{mL}$ ). ${ }^{1,25}$ The characteristics and demographics of the 17 SOC and 16 IVIG subjects are shown in Table 1. The subjects were well-matched with respect to age and underlying comorbidities.

Consistent with the pattern of COVID-19 infection in San Diego, $>80 \%$ of enrolled subjects in each arm were Latino and predominantly male. Concomitant therapies were also evenly distributed in both arms, with about half of the enrolled subjects in each arm receiving remdesivir. Convalescent plasma was administered to 5 subjects (3 SOC, 2 IVIG). Glucocorticoid therapy was part of the IVIG protocol and used as a premedication (40 mg IV methylprednisolone before each IVIG dose for 3 days) whereas 10 of 17 SOC subjects received some glucocorticoid therapy. Five IVIG subjects received additional glucocorticoid therapy beyond the methylprednisolone per protocol dosing. The SOC subjects receiving glucocorticoids received them for a median of 11 days.

Laboratory data was well matched between the two treatment groups, as shown in Table 2. Significant leukocytosis $>12,000 / \mathrm{mm}^{3}$ was uncommon, present in only 4 total subjects ( $3 \mathrm{IVIG}$ and $1 \mathrm{SOC}$ ) and procalcitonin averaged $0.25 \mathrm{ng} / \mathrm{mL}$ for both groups, with a maximum of $0.80 \mathrm{ng} / \mathrm{mL}$. D-dimer concentrations at the time of enrollment were numerically higher in the IVIG group compared to the SOC, with means of 1456 and 
medRxiv preprint doi: https://doi.org/10.1101/2020.07.20.20157891; this version posted July 25, 2020. The copyright holder for this preprint

(which was not certified by peer review) is the author/funder, who has granted medRxiv a license to display the preprint in perpetuity.

It is made available under a CC-BY-NC-ND 4.0 International license .

$758 \mathrm{ng} / \mathrm{mL}$, respectively (normal $<500 \mathrm{ng} / \mathrm{mL}$ ). Median (range) of D-dimer

concentrations were 827 (386-7028) and 691 (283-1657) in IVIG and SOC groups, respectively. One IVIG and 4 SOC subjects had normal D-dimer concentrations at enrollment.

Clinical outcomes. The two patient groups were well-matched with respect to their Charlson comorbidity index and severity of illness APACHE 2 scores (Figure 2). Median Charlson index was 2 for both groups. Median APACHE 2 score was 7 for SOC and 7.5 the IVIG study group. Figure 2 demonstrates the subjects in the control SOC and treatment IVIG group that developed a need for mechanical ventilation after study enrollment, denoted as the red data points. An overall trend is for receipt of mechanical ventilation in the IVIG group in the 2 patients with highest comorbidity and illness severity scores, whereas in the SOC group mechanical ventilation requirement developed across the entire spectrum of scores.

Among the entire enrolled and evaluated subjects in each arm, 2 patients in the IVIG arm and 7 patients in the control SOC arm developed a need for mechanical ventilation. Among these 7 SOC patients, 6 received ventilation and 1 was made a 'do not intubate' and the patient expired within 24 hours. The difference in receipt of mechanical ventilation was not statistically significant between the two groups $(p=0.12$, Fisher exact test). Among subjects whose respiratory failure progressed to the need for mechanical ventilation, 1 of 2 IVIG subjects and 2 of 3 control subjects also received concomitant convalescent plasma. Concomitant glucocorticoid therapy was given to 5 of the 7 control subjects who progressed to mechanical ventilation. The use of remdesivir was 
medRxiv preprint doi: https://doi.org/10.1101/2020.07.20.20157891; this version posted July 25, 2020. The copyright holder for this preprint

dependent on its availability after May 13, 2020 and therefore all patients admitted after that date whose respiratory failure progressed to needing mechanical ventilation received it. This resulted in 1 of 2 IVIG patients and 3 of 7 SOC subjects that required ventilation receiving remdesivir.

Alveolar-arterial (A-a) gradients were calculated directly from arterial blood gas or estimated based on $\mathrm{PaO}_{2}$ and $\mathrm{FiO}_{2}$ measurement. Based on an increase in APACHE II severity of illness scoring associated with achieving and A-a gradient of $>200 \mathrm{~mm} \mathrm{Hg}$ (+2 points), subjects were stratified into those with A-a gradient $\leq 200 \mathrm{~mm} \mathrm{Hg}$ or $>200$ $\mathrm{mm} \mathrm{Hg}$, corresponding to $\mathrm{PaO}_{2} / \mathrm{FiO}_{2}$ of $<140$, or the approximate requirement of 6 liters $\mathrm{O}_{2}$ by nasal cannula for a $\mathrm{PaO} 2$ of $\leq 92 \%$. As shown in Figure $3 \mathrm{~A}$, none of the 7 subjects (5 SOC, 2 IVIG) with A-a gradient $\leq 200 \mathrm{~mm} \mathrm{Hg}$ progressed to mechanical ventilation, but for subjects with A-a gradient of $>200 \mathrm{~mm} \mathrm{Hg}$ at enrollment, the progression to mechanical ventilation was $7 / 12(58 \%)$ in the SOC control arm vs $2 / 14$ $(14 \%)$ in the IVIG, a difference that was statistically significant $(p=0.038$, Fisher Exact test).

Evaluation of overall hospital course, including length of hospital stay and length of ICU stay also was highly dependent on A-a gradient stratification. Among the 7 patients with A-a gradient $\leq 200 \mathrm{~mm} \mathrm{Hg}$, no patient required ICU stay during their illness and length of hospital stay were 3-8 days. However, for the subjects with A-a gradient $>200$ at enrollment, median length of hospital stay was 19 (range 4-30) and 11 (range 5-22) days for SOC and IVIG groups, respectively ( $p=0.013$, Mann Whitney U test, Figure 3B). Median ICU stay were 12.5 days (range 1-29) and 2.5 days (range $0-16$ ) for SOC and IVIG, respectively $(p=0.006$, Mann Whitney $U$ test, Figure $3 C)$. Total ventilator patient- 
medRxiv preprint doi: https://doi.org/10.1101/2020.07.20.20157891; this version posted July 25, 2020. The copyright holder for this preprint

(which was not certified by peer review) is the author/funder, who has granted medRxiv a license to display the preprint in perpetuity.

It is made available under a CC-BY-NC-ND 4.0 International license .

days were 98 days for SOC (5.8 days/patient enrolled) and 23 days for the IVIG group (1.4 days/patient enrolled). The supplementary Figure shows schematically the hospital stays from the time of admission of the 33 enrolled patients with respect to medical floor and ICU stays with and without mechanical ventilation.

Improvement in oxygenation was evaluated by examining the $\mathrm{PaO}_{2} / \mathrm{FiO}_{2}$ ratio at the day of enrollment and 7 days after enrollment in individual subjects for SOC (Figure 4A) and IVIG (Figure 4B). Differences in day $7 \mathrm{PaO}_{2} / \mathrm{FiO}_{2}$ minus enrollment $\mathrm{PaO}_{2} / \mathrm{FiO}_{2}$ are shown in Figure $4 \mathrm{C}$ for both groups, with negative numbers representing worsening in oxygenation. Among the entire subject population, median improvement $\mathrm{PaO}_{2} / \mathrm{FiO}_{2}$ for IVIG was +153 (range +35 to +330 ) and was better than SOC +90 (range -115 to $+280)$, but did not reach statistical significance $(p=0 \cdot 057$, Mann Whitney $U$ test).

However, when refocusing on the higher-risk patients with A-a gradient $>200$ at enrollment, median improvement of $\mathrm{PaO}_{2} / \mathrm{FiO}_{2}$ for IVIG was significantly greater than SOC, with median (range) of $+131(+35$ to +330$)$ versus $+44 \cdot 5(-115$ to +157$)(p=0 \cdot 01$, Mann Whitney-U test).

Figure $4 \mathrm{C}$ denotes subjects in the SOC group who did not receive any glucocorticoid therapy as red data points. Seven subjects in SOC did not receive glucocorticoids, 4 of whom were in the low-risk group with A-a gradient $<200$. Of the remaining 3 patients, 2 progressed to requiring mechanical ventilation, one of which was made do not intubate and died. $\mathrm{PaO}_{2} / \mathrm{FiO}_{2}$ changes between enrollment and day 7 of the $10 \mathrm{SOC}$ patients who received glucocorticoid therapy (median 11 days) was median +53 (range -115 to +216), a difference that remained significantly lower than the IVIG group ( $p=0.0057$, Mann Whiney U test). 
medRxiv preprint doi: https://doi.org/10.1101/2020.07.20.20157891; this version posted July 25, 2020. The copyright holder for this preprint (which was not certified by peer review) is the author/funder, who has granted medRxiv a license to display the preprint in perpetuity. It is made available under a CC-BY-NC-ND 4.0 International license .

Adverse events, safety, and tolerability. Three subjects (18\%) in the SOC group and one subject (6\%) in the IVIG group died. The death in the IVG group occurred after the patient developed a Staphylococcus aureus pneumonia and then Escherichia coli bacteremia 4 and 6 days after mechanical ventilation, respectively. The SOC deaths included: 1 subject who developed progressive respiratory failure in need of mechanical ventilation who was then made 'do not intubate' and expired; 1 subject had care withdrawn after failing to make progress 20 days on mechanical ventilation; 1 subject developed Pseudomonas aeruginosa and Enterobacter cloacae ventilator-associated pneumonia and died after being on mechanical ventilation for 17 days. Tocilizumab was administered off-label to 3 SOC subjects after the endpoint of mechanical ventilation was reached. One subject died, one patient was discharged from the hospital, and one remained in the hospital ventilated at 30 days post-enrollment.

All subjects in the IVIG study arm tolerated IVIG without any adverse events being reported to the clinical study team. Notably, there were no reports of headache, allergic reactions, or thromboses described. All subjects were able to tolerate and complete all 3 daily doses of IVIG without incident. In addition to the bacterial superinfections described above, one additional IVIG subject developed an E. coli bacteremia without clear source while otherwise improving clinically from requiring high-flow to low-flow oxygen down to 2 liters by nasal cannula. The patient was prescribed a short course of antibiotics and was discharged home on room air. 
medRxiv preprint doi: https://doi.org/10.1101/2020.07.20.20157891; this version posted July 25, 2020. The copyright holder for this preprint (which was not certified by peer review) is the author/funder, who has granted medRxiv a license to display the preprint in perpetuity. It is made available under a CC-BY-NC-ND 4.0 International license.

Interleukin-6. A subset of enrolled subjects had serum IL-6 concentrations sent out to a commercial laboratory (ARUP Labs, Salt Lake City, UT) on blood drawn 24-48 hrs postenrollment. These would be reflective of having received no IVIG in the SOC control arm and 1 or 2 doses of IVIG in the IVIG treatment arm. Figure 5 shows significantly reduced IL-6 serum concentrations in the IVIG group (median 5, range 2-9 pg/mL) compared to the SOC group (median 18, range 3.6-141 pg/mL). 
medRxiv preprint doi: https://doi.org/10.1101/2020.07.20.20157891; this version posted July 25, 2020. The copyright holder for this preprint

(which was not certified by peer review) is the author/funder, who has granted medRxiv a license to display the preprint in perpetuity.

It is made available under a CC-BY-NC-ND 4.0 International license .

\section{Discussion}

In this first prospective randomized study evaluating IVIG in the treatment of COVID-19 infection, the use of IVIG reduced the rate of progression of respiratory failure requiring mechanical ventilation in COVID-19 patients (13\% with IVIG vs. $41 \%$ without IVIG, $p=0.12$ ). While this did not achieve statistical significance among the collective subject cohorts, the reduced rate of progression to mechanical ventilation with IVIG achieved statistical significance among the subset with a calculated or estimated A-a gradient of $>$ $200 \mathrm{~mm} \mathrm{Hg}(14 \%$ with IVIG vs. $58 \%$ without IVIG, $p=0.038)$. This finding points not only to the potential benefit of IVIG in COVID-19, but the importance of optimal patient selection for IVIG in maximizing clinical benefit. COVID-19 patients with mild hypoxia may never warrant anything more than supportive low-flow oxygen therapy, such that intervening with IVIG may not change the course of an otherwise benign disease course. A cutoff A-a gradient of $>200 \mathrm{~mm} \mathrm{Hg}$ was chosen due to the fact that this represents a notable risk increase in APACHE 2 score calculation in predicting mortality. The benefits of IVIG in reducing respiratory failure morbidity in COVID-19 patients was further supported by the significant shortening of duration of length hospital stay and ICU length of stay, and improvement in oxygenation $\left(\mathrm{PaO}_{2} / \mathrm{FiO}_{2}\right)$ at day 7 . Mortality was numerically reduced from $3 / 17(18 \%)$ to $1 / 16(6 \%)$ with IVIG in this study but not significant due to small sample size.

A multisystem inflammatory syndrome (MIS) has been recently described in children and adolescents convalescing from COVID-19 infection. This syndrome which includes fever, rash, myocardial dysfunction, gastrointestinal disturbance, hypotension, coagulopathy, and elevated blood markers of inflammation (eg. C-reactive protein) is 
medRxiv preprint doi: https://doi.org/10.1101/2020.07.20.20157891; this version posted July 25, 2020. The copyright holder for this preprint

clinically reminiscent of Kawasaki's disease, a well-recognized idiopathic severe febrile illness of childhood. ${ }^{23,24}$ This raises the possibility that the pathophysiology of COVID-19 infection in children and adults may be similar even though clinical manifestations are different. Interestingly, the mainstay of therapy for Kawasaki disease for decades has been IVIG, and children with MIS have been successfully treated with IVIG, lending further support of a potential benefit of IVIG in adults with COVID-19. ${ }^{17,23,24}$ Although the sample size was small, IVIG was well-tolerated in this study and did not require discontinuation and the three-day course was completed by all subjects. The hypercoaguability conferred by IVIG raised theoretical concerns when superimposed on the recently observed COVID-19 induced thrombotic events, but no cases of arterial or venous thrombosis associated with IVIG were identified in this study. This is particularly notable given that 15 of the 16 subjects in the IVIG treatment arm had elevated D-dimer concentrations at the time of enrollment, suggestive of some form of intravascular thrombosis and fibrinolysis consistent with the pathophysiology of more severe COVID19 cases. Furthermore, antiphospholipid antibodies have been described in COVID-19 patients and IVIG has been used has been used previously to treat the antiphospholipid antibody syndrome..$^{25,26}$

The importance of IL-6 in the cytokine release syndrome (CRS) in COVID-19 has been suggested by the Th17 lymphocyte populations found in patients with alveolar injury, initiating the study of IL-6 receptor blockade in the treatment of severe COVID-19 infection. ${ }^{11-14,27}$ Data appears promising but randomized control data beyond descriptive case series is still awaited. In this study, the subset of patients who had IL-6 concentrations measured within $24-48$ hours of study enrollment showed significantly 
medRxiv preprint doi: https://doi.org/10.1101/2020.07.20.20157891; this version posted July 25, 2020. The copyright holder for this preprint

lower IL-6 levels among those who received IVIG compared to the SOC group. While pre-enrollment IL-6 levels were not measured, reduction of IL-6 production by IVIG has been previously shown and further validates the potential role of IVIG in severe COVID19 infection. ${ }^{28}$

As a blood product derived from healthy donors, efficacy of IVIG may in fact improve over time as a higher percentage of the population of donors develops neutralizing antibodies to the SARS-CoV2 virus. Convalescent plasma may offer some benefit in a subset of COVID-19 patients per a recent randomized study, so these benefits could theoretically be added to the immunomodulatory effects of IVIG as the donor pool of IVIG develops increased immunity to SARS-CoV-2. ${ }^{29}$

This study has some important limitations. First, this study was performed in just 2 hospitals in one US city, resulting in a fairly homogenous population of younger Latino patients where results may not automatically translate to other patient settings.

Secondly, while prospective and randomized, the study was not blinded and therefore subject to bias. This was reduced by the fact that the clinical investigators had minimal clinical decision-making on these patients, particularly regarding the endpoints of mechanical ventilation and discharge from the hospital. Third, the concomitant use of methylprednisolone therapy may have confounded the results. At the time of study initiation, the use of glucocorticoid therapy was controversial, possibly causing harm in COVID-19. We decided to give methylprednisolone $40 \mathrm{mg}$ (equivalent to approximately $7 \cdot 5 \mathrm{mg}$ dexamethasone) to mitigate any potential adverse effects of IVIG such as headache, theorizing that benefit would outweigh risk by increasing tolerability of IVIG. Just recently, however, the benefit of glucocorticoid therapy was shown with $6 \mathrm{mg}$ of 
medRxiv preprint doi: https://doi.org/10.1101/2020.07.20.20157891; this version posted July 25, 2020. The copyright holder for this preprint (which was not certified by peer review) is the author/funder, who has granted medRxiv a license to display the preprint in perpetuity. It is made available under a CC-BY-NC-ND 4.0 International license .

dexamethasone for 10 days. ${ }^{30}$ While there may have been a small benefit rendered by this premedication, it is unlikely that the difference in outcomes between the two groups rested on this intervention. This is supported by the fact that the benefits of IVIG were significant even when comparison was made to the subset of SOC patients that received glucocorticoid therapy. Fourth, the sample size was small, which markedly reduced the power and strength of the positive findings, particularly given that COVID19 treatment standards have been a moving target. The 6-week study enrollment period saw a shifting attitude towards favoring glucocorticoids, the availability of remdesivir, and the movement away from early intubation/mechanical ventilation in favor of more aggressive self-proning protocols. ${ }^{31,32}$ Finally, severe comorbidities like severe renal disease and heart failure that were not highly represented in this group of patients may pose particular challenges due to their potentially poor tolerability of the volume load of IVIG therapy during COVID-19 infection.

In summary, this pilot study showed that IVIG $0.5 \mathrm{~g} / \mathrm{kg}$ daily for 3 days reduced progression of respiratory failure requiring mechanical ventilation, total length of hospital stay, and ICU length of stay, and improved oxygenation at 7 days when given after premedication with methylprednisolone $40 \mathrm{mg}$ to COVID-19 patients with a calculated or estimated A-a gradient of $>200 \mathrm{~mm} \mathrm{Hg}\left(\mathrm{PaO}_{2} / \mathrm{FiO}_{2}<140, \mathrm{PaO}_{2} \leq 92 \%\right.$ on $\geq 6 \mathrm{~L}$ nasal cannula). This study served as the foundation of a larger phase 3, multicenter, doubleblind placebo-controlled trial evaluating IVIG in COVID-19, which is currently enrolling patients (clinicaltrials.gov, NCT04400058), and which will hopefully validate these findings. 


\section{Acknowledgments}

Guarantor statement: George Sakoulas, MD takes responsibility for (is the guarantor of) the content of the manuscript, including the data and analysis

Author Contributions:

Clinical trial design: GS, MG, FH

Clinical trial execution: $\mathrm{GS}, \mathrm{MG}, \mathrm{FH}$

Data analysis: GS, MG, RK, KLG, MH, AV, MG(2), VNKD, FH

Manuscript First Draft: GS

Manuscript Editing: GS, MG, RK, KLG, MH, AV, MG(2), VNKD, FH

Figures: GS

Financial Disclosures: This research was supported and funded by Octapharma USA, Inc (Paramus, NJ).

Octapharma USA, Inc did not influence the design or execution of the study, and did not have a role in data analysis or manuscript preparation. 
medRxiv preprint doi: https://doi.org/10.1101/2020.07.20.20157891; this version posted July 25, 2020. The copyright holder for this preprint (which was not certified by peer review) is the author/funder, who has granted medRxiv a license to display the preprint in perpetuity. It is made available under a CC-BY-NC-ND 4.0 International license .

\section{References}

1. Chen N, Zhou M, Dong X, et al. Epidemiological and clinical characteristics of 99 cases of 2019 novel coronavirus pneumonia in Wuhan, China: a descriptive study. Lancet 2020;395:5017-513; doi: 10.1016/S0140-6736(20)30211-7.

2. Siddiqu HK, Mehra MR. COVID-19 IIIness in Native and Immunosuppressed States: A Clinical- Therapeutic Staging Proposal. Journal of Heart and Lung Transplantation. doi: 10.1016/j.healun.2020.03.012.

3. Qin C, Zhou L, Hu Z, et al. Dysregulation of immune response in patients with COVID-19 in Wuhan, China. Clin Infect Dis 2020; doi: 10.1093/cid/ciaa248.

4. Chen J, Lau YF, Lamirande EW, et al. Cellular immune responses to severe acute respiratory syndrome coronavirus (SARS-CoV) infection in senescent BALB/c mice: CD4+ T cells are important in control of SARS-CoV infection. $J$ Virol. 2010;84(3):1289-1301. doi:10.1128/JVI.01281-09.

5. Beigel JH, Tomashek KM, Dodd LE, et al. Remdesivir for the Treatment of Covid19 - Preliminary Report [published online ahead of print, 2020 May 22]. N Engl J Med. 2020;NEJMoa2007764. doi:10.1056/NEJMoa2007764

6. Wang Y, Zhang D, Du G, et al. Remdesivir in adults with severe COVID-19: a randomised, double-blind, placebo-controlled, multicentre trial [published correction appears in Lancet. 2020 May 30;395(10238):1694]. Lancet. 2020;395(10236):1569-1578. doi:10.1016/S0140-6736(20)31022-9

7. Goldman JD, Lye DCB, Hui DS, et al. Remdesivir for 5 or 10 Days in Patients with Severe Covid-19 [published online ahead of print, 2020 May 27]. N Engl J Med. 2020;10.1056/NEJMoa2015301. doi:10.1056/NEJMoa2015301 
medRxiv preprint doi: https://doi.org/10.1101/2020.07.20.20157891; this version posted July 25, 2020. The copyright holder for this preprint (which was not certified by peer review) is the author/funder, who has granted medRxiv a license to display the preprint in perpetuity. It is made available under a CC-BY-NC-ND 4.0 International license .

8. Taccone FS, Gorham J, Vincent JL. Hydroxychloroquine in the management of critically ill patients with COVID-19: the need for an evidence base. Lancet Respir Med. 2020;8(6):539-541. doi:10.1016/S2213-2600(20)30172-7

9. Ye Q, Wang B, Mao J. The pathogenesis and treatment of the 'Cytokine Storm' in COVID-19. J Infect. 2020;80(6):607-613. doi:10.1016/j.jinf.2020.03.03

10. Mehta P, McAuley DF, Brown M, et al. COVID-19: consider cytokine storm syndromes and immunosuppression. Lancet 2020;395:1033-1034; doi:10.1016/S0140-6736(20)30628-0.

11. Xu X, Han M, Li T, et al. Effective treatment of severe COVID-19 patients with tocilizumab. Proc Natl Acad Sci U S A. 2020;117(20):10970-10975. doi:10.1073/pnas.2005615117

12. Luo P, Liu Y, Qiu L, Liu X, Liu D, Li J. Tocilizumab treatment in COVID-19: A single center experience. J Med Virol. 2020;92(7):814-818. doi:10.1002/jmv.25801

13.Zhang C, Wu Z, Li JW, Zhao H, Wang GQ. Cytokine release syndrome in severe COVID-19: interleukin-6 receptor antagonist tocilizumab may be the key to reduce mortality. Int J Antimicrob Agents. 2020;55(5):105954. doi:10.1016/j.jjantimicag.2020.105954

14. Toniati P, Piva S, Cattalini M, et al. Tocilizumab for the treatment of severe COVID-19 pneumonia with hyperinflammatory syndrome and acute respiratory failure: A single center study of 100 patients in Brescia, Italy. Autoimmun Rev. 2020;19(7):102568. doi:10.1016/j.autrev.2020.102568 
medRxiv preprint doi: https://doi.org/10.1101/2020.07.20.20157891; this version posted July 25, 2020. The copyright holder for this preprint (which was not certified by peer review) is the author/funder, who has granted medRxiv a license to display the preprint in perpetuity. It is made available under a CC-BY-NC-ND 4.0 International license .

15. Fischer A, Rausell A. Primary immunodeficiencies suggest redundancy within the human immune system. Sci Immunol. 2016;1(6):eaah5861. doi:10.1126/sciimmunol.aah5861

16. Pawar A, Desai RJ, Solomon DH, et al. Risk of serious infections in tocilizumab versus other biologic drugs in patients with rheumatoid arthritis: a multidatabase cohort study. Ann Rheum Dis. 2019;78(4):456-464. doi:10.1136/annrheumdis2018-214367

17. Perez EE, Orange JS, Bonilla F, et al. Update on the use of immunoglobulin in human disease: A review of evidence. J Allergy Clin Immunol 2017;139: S1-S46; doi: 10.1016/j.jaci.2016.09.023.

18. Galeotti C, Kaveri SV, Bayry J. IVIG-mediated effector functions in autoimmune and inflammatory diseases. Int Immunol. 2017;29(11):491-498. doi:10.1093/intimm/dxx039

19. Shao Z, Feng Y, Zhong L, et al. Clinical efficacy of intravenous immunoglobulin therapy in critical patients with COVID-19: a multicenter retrospective cohort study. MedRxIV 2020; doi: 10.1101/2020.04.11

20. Xie Y, Cao S, Li Q, et al. Effect of regular intravenous immunoglobulin therapy on prognosis of severe pneumonia in patients with COVID-19. J Infect 2020; doi: 10.1016/j.jinf.2020.03.044.

21.Zhou AG, Xie SM, Zhang J, et al. Short-term moderate-dose corticosteroid plus immunoglobulin effectively reverses COVID-19 patients who have failed lowdose therapy. Preprints 2020; doi: 10.20944/preprints202003.0065.v1. 
medRxiv preprint doi: https://doi.org/10.1101/2020.07.20.20157891; this version posted July 25, 2020. The copyright holder for this preprint (which was not certified by peer review) is the author/funder, who has granted medRxiv a license to display the preprint in perpetuity. It is made available under a CC-BY-NC-ND 4.0 International license .

22. Cao W, Liu X, Bai T, et al. High-dose intravenous immunoglobulin as a therapeutic option for deteriorating patients with coronavirus disease 2019. Open Forum Infect Dis 2020; 7; doi: 10.1093/ofid/ofaa102.

23. Verdoni L, Mazza A, Gervasoni A, et al. An outbreak of severe Kawasaki-like disease at the Italian epicentre of the SARS-CoV-2 epidemic: an observation cohort study. Lancet 2020; doi: 10.1016/S0140-6736(20)31103-X

24. Belhadjer Z, Méot M, Bajolle F, et al. Acute heart failure in multisystem inflammatory 119 syndrome in children (MIS-C) in the context of global SARSCoV-2 pandemic. Circulation 2020; 120 doi:

10.1161/CIRCULATIONAHA.120.048360.

25.Zhang Y, Xiao M, Zhang S, et al. Coagulopathy and Antiphospholipid Antibodies in Patients with Covid-19. N Engl J Med. 2020;382(17):e38. doi:10.1056/NEJMc2007575

26. Cervera R, Rodríguez-Pintó I, Espinosa G. The diagnosis and clinical management of the catastrophic antiphospholipid syndrome: A comprehensive review. J Autoimmun. 2018;92:1-11. doi:10.1016/j.jaut.2018.05.007

27. Liu F, Li L, Xu M, et al. Prognostic value of interleukin-6, C-reactive protein, and procalcitonin in patients with COVID-19. J Clin Virol. 2020;127:104370. doi:10.1016/j.jcv.2020.104370

28. Purswani, M., Johann-Liang, R., Neeley, M. et al. Effect of Intravenous Immune Globulin (IVIG) on Interleukin-6 (IL-6) Production by Whole Blood $\diamond$ 894. Pediatr Res 43, 154 (1998). https://doi.org/10.1203/00006450-199804001-00915 
29. Li L, Zhang W, Hu Y, et al. Effect of convalescent plasma therapy on time to clinical improvement in patients with severe and life-threatening COVID-19: a randomized clinical trial. JAMA. Published online June 3, 2020. doi:10.1001/jama.2020.10044

30. RECOVERY Collaborative Group. Effect of dexamethasone in hospitalized patients with COVID-19-preliminary report. https://www.medrxiv.org/content/10.1101/2020.06.22.20137273v1.full.pdf

31. Elharrar X, Trigui Y, Dols AM, et al. Use of Prone Positioning in Nonintubated Patients With COVID-19 and Hypoxemic Acute Respiratory Failure [published online ahead of print, 2020 May 15]. JAMA. 2020;323(22):2336-2338. doi:10.1001/jama.2020.8255

32. Caputo ND, Strayer RJ, Levitan R. Early Self-Proning in Awake, Non-intubated Patients in the Emergency Department: A Single ED's Experience During the COVID-19 Pandemic. Acad Emerg Med. 2020;27(5):375-378. doi:10.1111/acem.13994 
Table 1. Enrolled patient demographics and characteristics

\begin{tabular}{|c|c|c|c|}
\hline \multicolumn{2}{|c|}{ IVIG $(n=16)$} & \multicolumn{2}{|c|}{$\operatorname{soc}(n=17)$} \\
\hline 54 & & 54 & \\
\hline 58 & & 51 & \\
\hline 10 & (63) & 10 & (59) \\
\hline 13 & $(81)$ & 15 & (88) \\
\hline 3 & (19) & $\begin{array}{l}2 \\
348\end{array}$ & (12) \\
\hline
\end{tabular}

Admit to Enroll (days) Median (Range) $1.5(0-8)$

Comorbidities N (\%)

Diabetes 6

Mean HgbA1c (\%) $\quad 10.1$

Hypertension 4

Chronic Kidney Disease 0

Coronary Artery Disease 1

Congestive Heart Failure 1

Asthma/COPD

Current Smoker

Former Smoker

Immunocompromised
1

2

1

8

2

$16^{*}$
(38)

(25)

(0)

(6)

(6)

(6)

(6)
6

6.4

7

1

0

1

2

1

1

0

(0)

Other COVID-19 Therapies N (\%)

Remdesivir

Convalescent Plasma

Any Glucocorticoid Therapy
(100)
9

3

10

*All IVIG patients received at least methylprednisolone $40 \mathrm{mg}$ IV 30-60 minutes before each dose ( 3 days) per protocol to mitigate probability of headache associated with IVIG therapy. 


\section{Table 2. Mean Values of Relevant Laboratory Data for Study Groups}

IVIG (n=16)

WBC $\left(x 1000 / \mathrm{mm}^{3}\right)$

Absolute Lymphocyte Count

Platelet $\left(\mathrm{x} 1000 / \mathrm{mm}^{3}\right)$

Hemoglobin $(\mathrm{g} / \mathrm{dL})$

Creatinine $(\mathrm{mg} / \mathrm{dL})$

C-reactive protein $(\mathrm{mg} / \mathrm{L})$

Procalcitonin $(\mathrm{ng} / \mathrm{mL})$

Ferritin (ng/mL)

D-dimer (ng/mL)
7.9

0.8

256

247

13.0

13.4

0.78

0.85

142

140

0.25

0.25

990

1014

1456

758 


\section{Figure Legends}

Figure 1. Consort Diagram of Enrolled Patients

Figure 2. Distribution of Charlson comorbidity index (A) and APACHE 2 scores (B) of enrolled study subjects in both treatment arms, showing even distribution of chronic illness and acute severity of illness. Horizontal bars denote median values. Red points indicate patients who ultimately required a need for mechanical ventilation.

Figure 3. A. Rates of mechanical ventilation in study subjects stratified by A-a gradient. Among patients with A-a gradient $>200 \mathrm{~mm} \mathrm{Hg}$, receipt of IVIG reduced rates of mechanical ventilation ( ${ }^{*} \mathrm{p}=0.038$, Fisher Exact test). B. Total length of hospital stay (days) among patients in SOC vs. IVIG with A-a gradient $>200 \mathrm{~mm} \mathrm{Hg}$. Median stay (horizontal bar) SOC 19 days vs. IVIG 11 days, $p=0.01$ Mann Whitney U test. C. Length of ICU stay (days) among patients in SOC vs. IVIG with A-a gradient $>200 \mathrm{~mm} \mathrm{Hg}$. Median (horizontal bar) stay SOC 12.5 days vs. IVIG 2.5 days, $p=0.006$ Mann Whitney $\mathrm{U}$ test.

Figure 4. Individual patient progress of $\mathrm{PaO}_{2} / \mathrm{FiO}_{2}$ at day of enrollment (day 0 ) and 7 days later in control SOC group (A) and IVIG group (B). Patients who were discharged and the one patient that died before day 7 had values placed from the last available day. The absolute differences for each group are shown in part $C$. Red data points denote patients who did not receive any glucocorticoid therapy. Differences in 7-day $\mathrm{PaO}_{2} / \mathrm{FiO}_{2}$ showed greater improvement oxygenation in IVIG-treated patients when compared to the entire SOC cohort ( $p=0 \cdot 057$, Mann Whitney $U$ test), but became significant after considering only those patients with A-a gradient at enrollment of $>200$ ( $p=0.01$, Mann Whitney $U$ ) and when comparing IVIG vs only SOC patients who received glucocorticoid therapy $(p=0.025$, Mann Whitney $U$ ). 
medRxiv preprint doi: https://doi.org/10.1101/2020.07.20.20157891; this version posted July 25, 2020. The copyright holder for this preprint (which was not certified by peer review) is the author/funder, who has granted medRxiv a license to display the preprint in perpetuity. It is made available under a CC-BY-NC-ND 4.0 International license.

Figure 5. Serum interleukin-6 concentrations of a subset of SOC controls $(n=11)$ and IVIG ( $n=13)$ treatment subjects obtained 24-48 hr after enrollment. Median IL-6 18 $\mathrm{pg} / \mathrm{mL}$ in SOC vs $5 \mathrm{pg} / \mathrm{mL}$ in IVIG group are denoted by the horizontal bar $(\mathrm{p}=0.0012$, Mann Whitney u test). 
medRxiv preprint doi: https://doi.org/10.1101/2020.07.20.20157891; this version posted July 25, 2020. The copyright holder for this preprint (which was not certified by peer review) is the author/funder, who has granted medRxiv a license to display the preprint in perpetuity. It is made available under a CC-BY-NC-ND 4.0 International license .

\section{Figure 1}

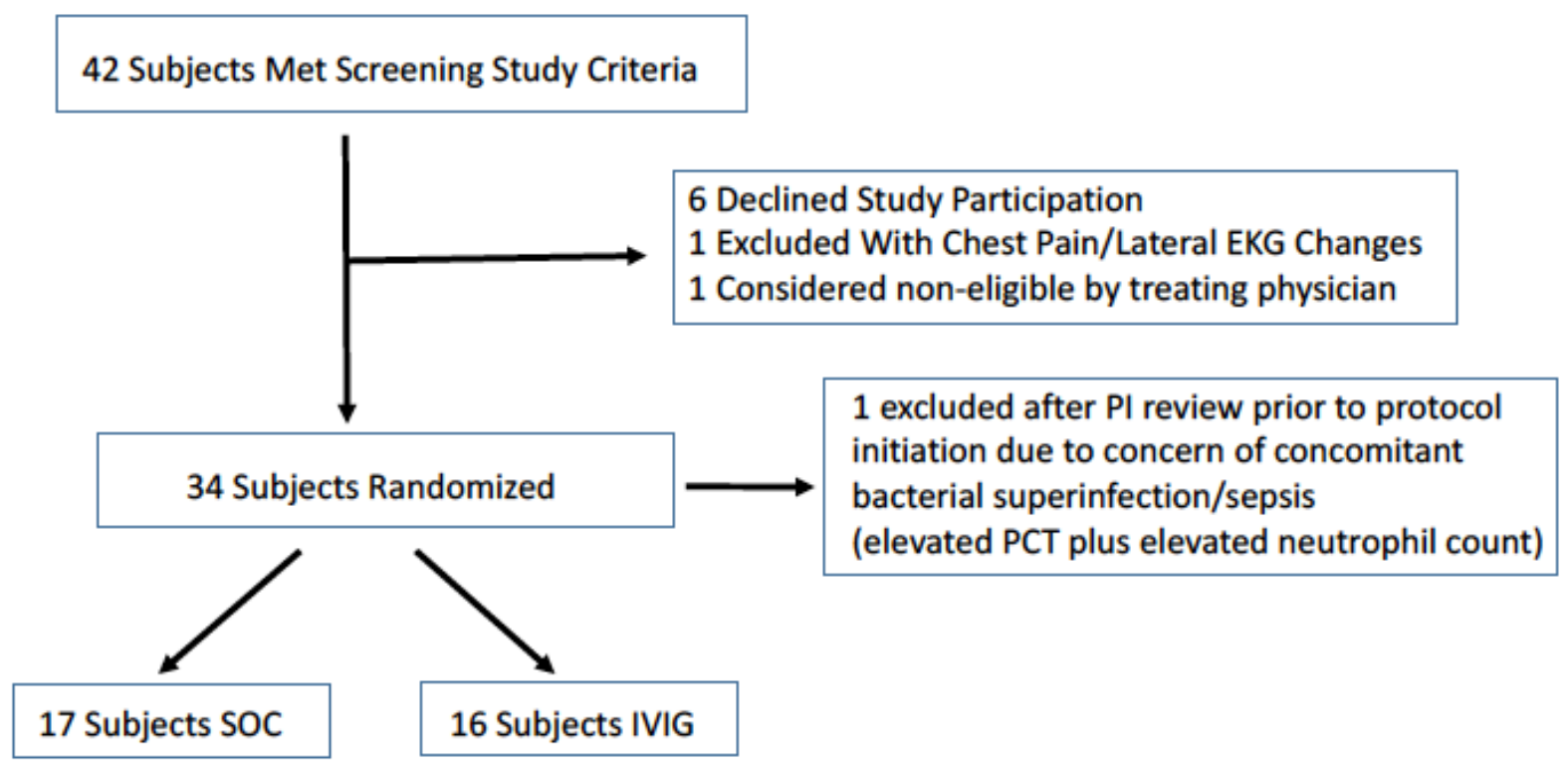


medRxiv preprint doi: https://doi.org/10.1101/2020.07.20.20157891; this version posted July 25, 2020. The copyright holder for this preprint (which was not certified by peer review) is the author/funder, who has granted medRxiv a license to display the preprint in perpetuity.

It is made available under a CC-BY-NC-ND 4.0 International license .

Figure 2

A

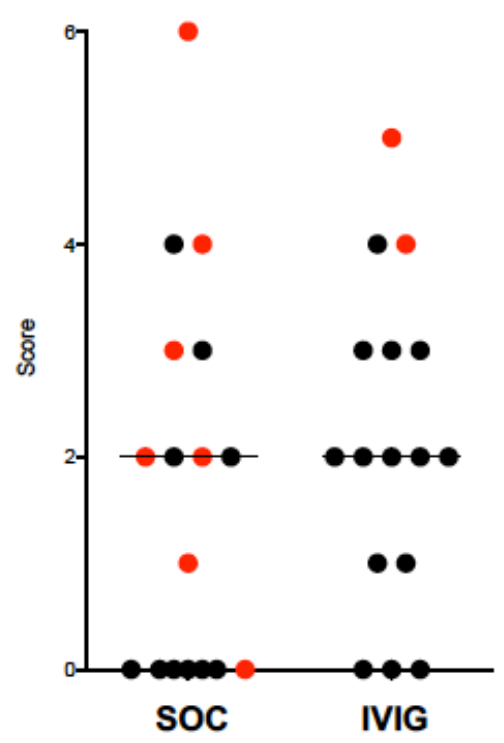

B

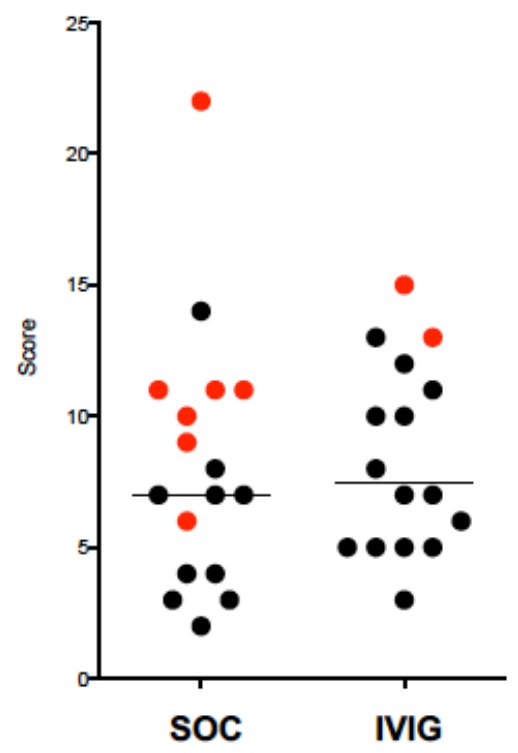

In Need of

Mechanical Ventilation

No Need of

Mechanical Ventilation 
medRxiv preprint doi: https://doi.org/10.1101/2020.07.20.20157891; this version posted July $25,2020$. The copyright holder for this preprint (which was not certified by peer review) is the author/funder, who has granted medRxiv a license to display the preprint in perpetuity.

\section{It is made available under a CC-BY-NC-ND 4.0 International license.}

Figure 3

A

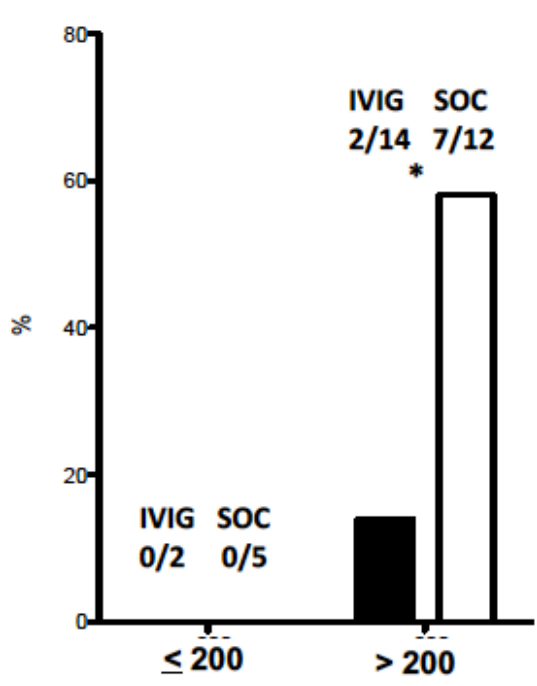

A-a Gradient (mm Hg)
B

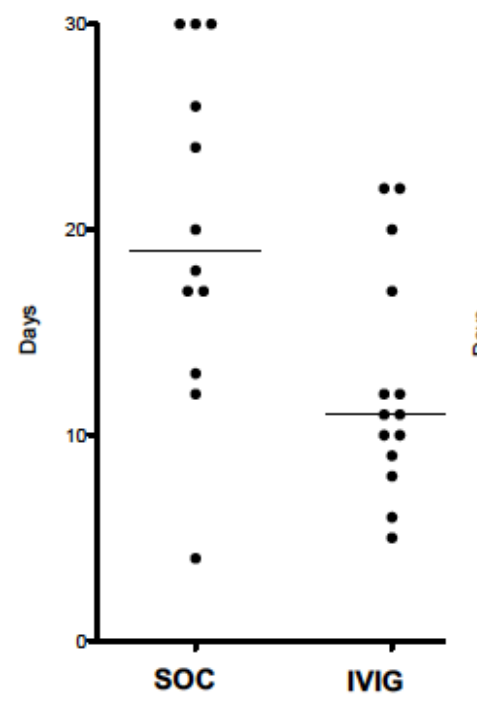

C

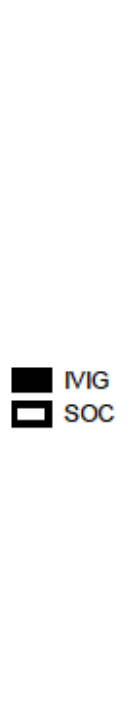

SOC

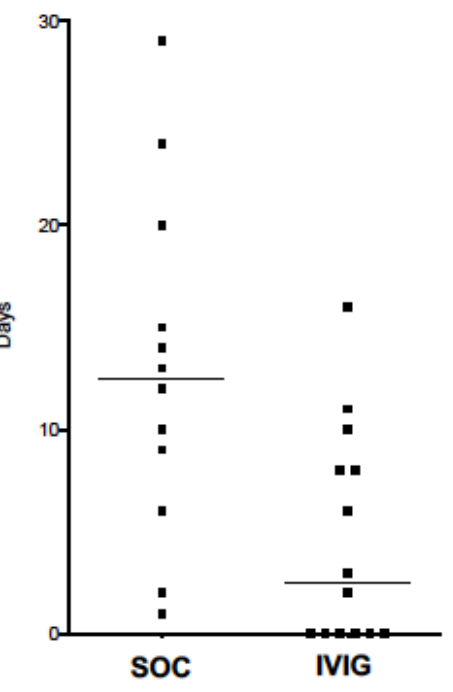


medRxiv preprint doi: https://doi.org/10.1101/2020.07.20.20157891; this version posted July 25, 2020. The copyright holder for this preprint (which was not certified by peer review) is the author/funder, who has granted medRxiv a license to display the preprint in perpetuity. It is made available under a CC-BY-NC-ND 4.0 International license.

Figure 4
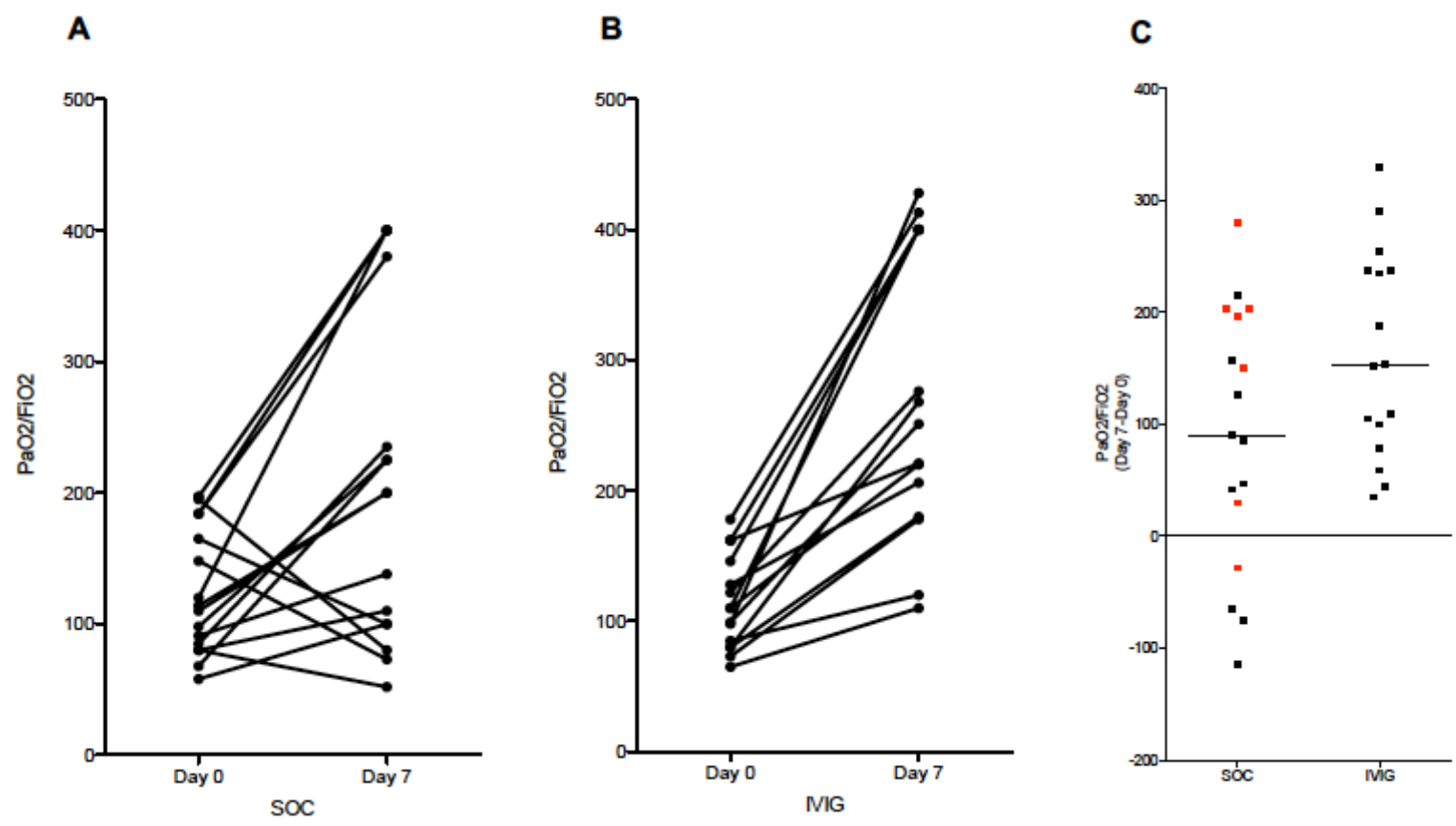
medRxiv preprint doi: https://doi.org/10.1101/2020.07.20.20157891; this version posted July 25, 2020. The copyright holder for this preprint (which was not certified by peer review) is the author/funder, who has granted medRxiv a license to display the preprint in perpetuity.

\author{
It is made available under a CC-BY-NC-ND 4.0 International license.
}

Figure 5

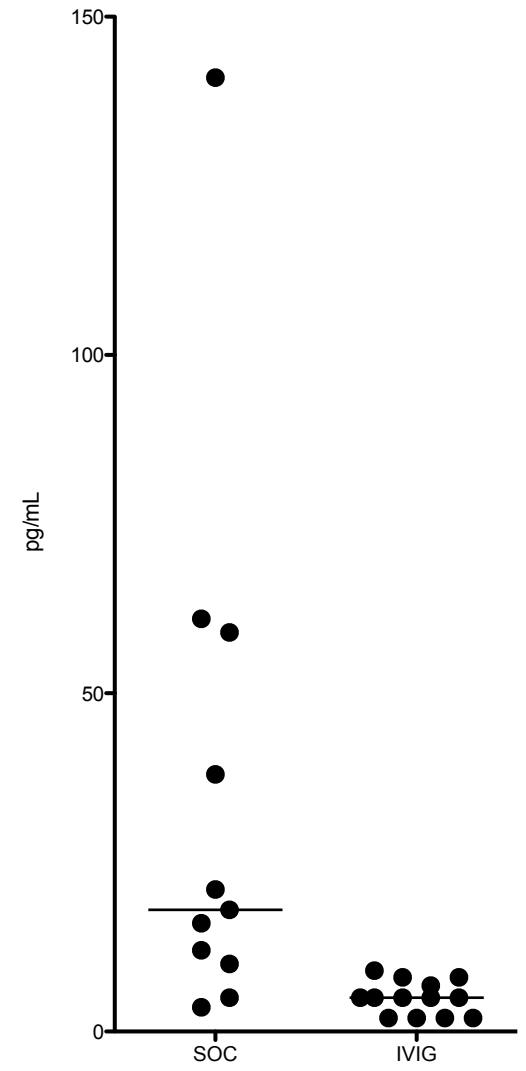


medRxiv preprint doi: https://doi.org/10.1101/2020.07.20.20157891; this version posted July 25, 2020. The copyright holder for this preprint (which was not certified by peer review) is the author/funder, who has granted medRxiv a license to display the preprint in perpetuity.

\section{Supplemental Figure}

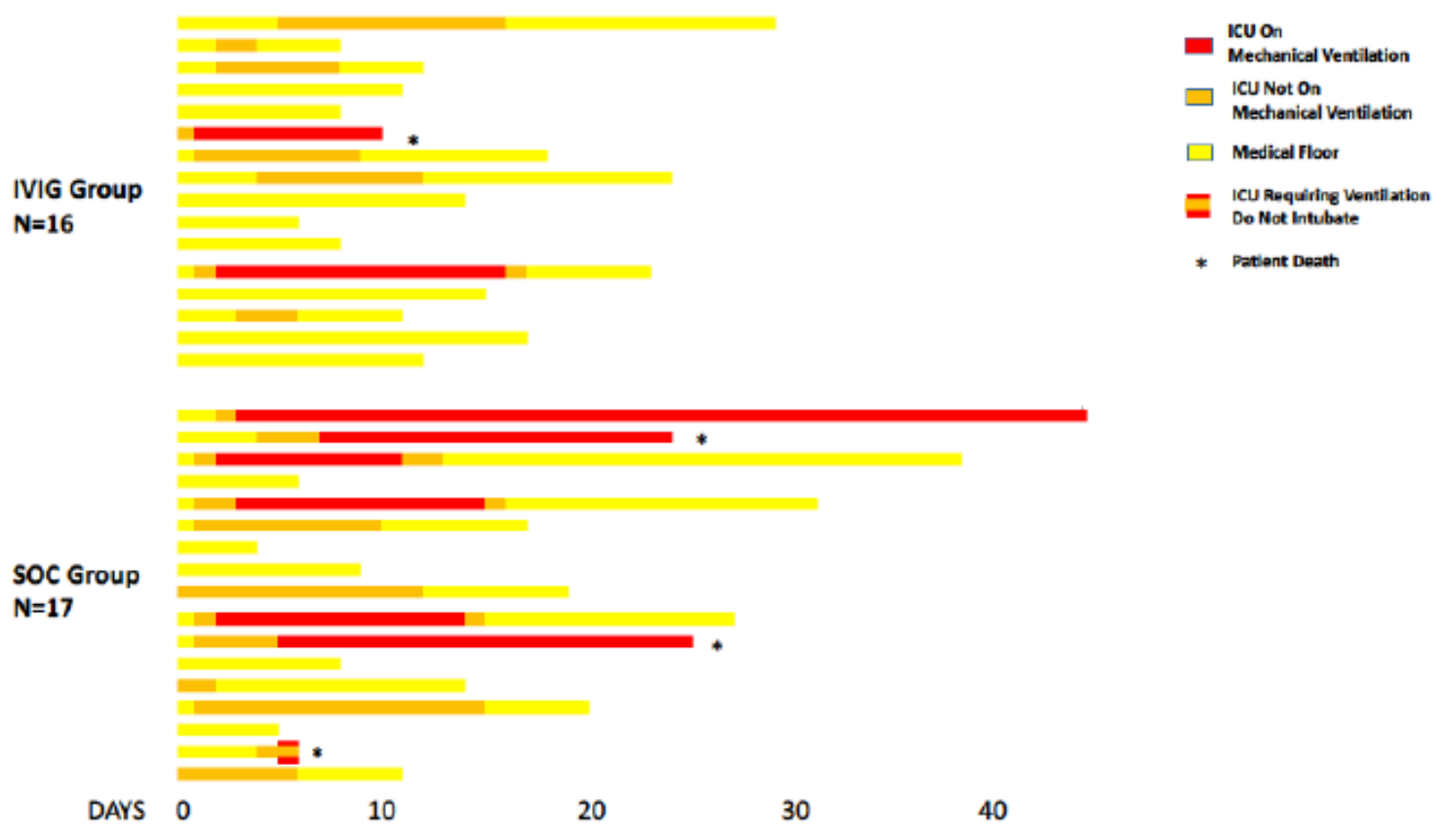

Schematic diagram of hospitalization from the time of admission of subjects. Death occurred in 3 SOC subjects and 1 IVIG subject $\left({ }^{*}\right)$. 